\title{
Evaluation of phenolic constituent, antioxidant and antibacterial activities of sugarcane molasses towards foodborne pathogens
}

\author{
${ }^{1}$ Shafiqa-Atikah, M.K., ${ }^{1 *}$ Nor-Khaizura, M.A.R., ${ }^{2}$ Mahyudin, N.A., ${ }^{1}$ Abas, F., \\ ${ }^{1}$ Nur-Syifa', J. and ${ }^{1}$ Ummul-Izzatul, Y. \\ ${ }^{1}$ Department of Food Science, Faculty of Food Science and Technology, Universiti Putra Malaysia, 43400 \\ UPM Serdang Selangor, Malaysia \\ ${ }^{2}$ Department of Food Service and Management, Faculty of Food Science and Technology, Universiti Putra \\ Malaysia, 43400 UPM Serdang Selangor, Malaysia
}

\section{Article history: \\ Received: 23 October 2019 \\ Received in revised form: 21 January 2020 \\ Accepted: 16 March 2020 Available Online: 15 April 2020}

\section{Keywords:}

Sugarcane molasses,

Antioxidant,

Antibacterial,

Phenolic compound,

Foodborne pathogens.

DOI:

https://doi.org/10.26656/fr.2017.4(S2).S05

\begin{abstract}
The employment of chemical synthetic as an antimicrobial agent in inhibiting microbial growth has become a major concern due to adverse health impact, food safety crisis and the pressure on food manufacturers. Essential bioactive compound in sugarcane molasses, a by-product from a sugar refinery process could be effective as an alternative antimicrobial substance. However, their antimicrobial properties are not understandable. This study aimed 1) to detect the total phenolic compounds present in sugarcane molasses extract and 2) to determine the antioxidants and antibacterial activities of sugarcane molasses extract towards foodborne pathogens. The phenolic compounds of sugarcane molasses extract were determined by UHPLC-MSMS. Antioxidant activities were estimated by a total phenolic compound assay and a 1,1-diphenyl-2-picrylhydrazyl (DPPH) assay. Meanwhile, antibacterial activities were carried out via disc diffusion, minimum inhibition concentrations (MICs) and minimum bactericidal concentrations (MBCs) assays. In this study, several extracted compounds were identified in sugarcane molasses extract and included gallic acid, phenylvaleric acids, quinic acid, tannic acid and 6-C-glucosyl-8-C-arabinosyl apigenin or arabinoysl-glucosylapigenin. The sugarcane molasses extract showed high total phenolic compounds with values of $7.6 \mathrm{mg}$ GAE/g extract. Meanwhile, antioxidant activities of sugarcane molasses extract were also found high and the $50 \%$ inhibitory concentration ( $\mathrm{IC}_{50}$ value) was about $0.79 \mathrm{mg} \mathrm{QE} / \mathrm{g}$. The inhibition zone against four foodborne pathogens, Staphylococcus aureus, Listeria monocytogenes, Escherichia coli and Salmonella enterica serovar Typhimurium ranged from $8.82 \pm 0.3 \mathrm{~mm}$ to $25.05 \pm 1.6 \mathrm{~mm}$. Meanwhile, the MICs of sugarcane molasses extract ranged from $3.125 \%$ to $6.25 \% \mathrm{v} / \mathrm{v}$ and $\mathrm{MBCs}$ were $6.25 \%$ to $>12.5 \% \mathrm{v} / \mathrm{v}$. In conclusion, sugarcane molasses extract is rich in phenolic compounds and has the potential to be applied as the natural antioxidant and antibacterial compounds.
\end{abstract}

\section{Introduction}

Since the last decade, synthetic chemical preservative has been used as an antimicrobial agent to control microbial food spoilage and extend the product shelf life (Saeed et al., 2019). However, the application of synthetic preservative has increased adverse health impact, food safety crisis and the pressure on food manufacturers. The abuse and misuse of synthetic preservative caused the rising of potential toxicity in food product and led to the development of antimicrobial resistance (Nychas, 1995; Bilal et al., 2017). With consumer awareness of food safety, synthetic-free preservative has become a high demand in the food market (Arshad and Batool, 2017). This reveals the need for an alternative antibacterial as one of the strategies to preserve food from spoilage and pathogenic microorganism.

Thus, extensive research to extract natural antibacterial from the plant is employed. This 'greener' technology is introduced as they were potent biochemical factories with phytomedicine component (Mohanraj, 2014). Plant materials which initially used as a traditional healer had been a precious resource for the medicinal and pharmaceutical field nowadays. This is 
because plant-originated medicine is more economical, environmental, and health-friendly compared to the synthetic antibacterial (Dahiya and Purkayastha, 2012). Phytoconstituent or phytobiotic in plant material such as alkaloid, tannins, phenolic acid, etc., are potentially effective as natural antibacterial therapy to many diseases (Edeoga et al., 2005; Dhama et al., 2014).

Sugarcane molasses is thick, dark, and sweet syrup derived from the sugar refining process (Arimi et al., 2014). It is composed by numerous essential elements; sugar, nitrogenous materials, organic acid and trace compounds provide multi-beneficial health consequence (Olbrich, 1963; Saska and Chou, 2002; Zhao et al. 2015). Besides, the composition of sugar cane molasses contain phenolic compounds that posing antioxidant (Saska and Chou, 2002; Guimarães et al., 2007; Valli et al., 2012), antibacterial (Takara et al., 2007; Chandra et al., 2008; Zhao et al., 2015), and DNA-damagingprotective activities (Guimarães et al., 2007; Abbas et al., 2014). Even though many researchers have carried out studies to evaluate different epidemiological of sugarcane molasses, only a little research reported on its antioxidant and antibacterial properties. Therefore, the objective of this work was to detect the total phenolic compounds present in sugarcane molasses extract, analyse the antioxidant activities of sugarcane molasses extract and explore its potent antibacterial activities against foodborne pathogens.

\section{Materials and methods}

\subsection{Sample preparation}

In this study, a sugarcane by-product, which is known as molasses, was used. The sugarcane molasses was received from Matahari Sdn. Bhd., Selangor, Malaysia.

\subsection{Extraction of sugarcane molasses}

A total of $60 \mathrm{~mL}$ of acidic ethanol solvent (Systerm, Selangor, Malaysia) and $2 \mathrm{~g}$ of sugar cane molasses were added into $100 \mathrm{~mL}$ beaker. The mixture was sonicated using ultrasound-assisted extraction machine for 90 mins. Next, the treatment was centrifuged at $1000 \mathrm{x} g$ for 10 mins. The supernatant was concentrated to $10 \mathrm{~mL}$ at $45^{\circ} \mathrm{C}$ in a vacuum and freeze-dried in $-35^{\circ} \mathrm{C}$ at 180 $\mathrm{mmHg}$ torr. The extract was re-dissolved in deionised water for next uses.

\subsection{Total polyphenol content}

The total phenolic content of sugarcane molasses was evaluated using the Folin-Ciocalteu method of Abas et al. (2014) with slight modifications. Briefly, $20 \mu \mathrm{L}$ of sugarcane molasses extract in DMSO, and $100 \mu \mathrm{L}$ of
Folin-Ciocalteu reagent was transferred to 96-well microplate. The mixture was mixed well and stayed in the dark for 5 mins. Then, $80 \mu \mathrm{L}$ of $75 \%$ sodium carbonate $(2 \%)$ was added to the filled well. The microplate was immediately placed in a microplate reader. The absorbance was measured at $765 \mathrm{~nm}$. Total phenolic content was calculated from a calibration curve of gallic acid and expressed as milligrams of gallic acid equivalent (GAE) per gram of sugarcane molasses extract.

\subsection{Radical scavenging activity}

Radical scavenging activity of sugarcane molasses extract was evaluated using 1,1-diphenyl-2picrylhydrazyl (DPPH) method described by Mohamad et al. (2004) with slight modifications. Briefly, $50 \mu \mathrm{L}$ of sugarcane molasses extract in DMSO, and $100 \mu \mathrm{L}$ of DPPH reagent was transferred to 96-well microplate. Then, $50 \mu \mathrm{L}$ of sugarcane molasses extract was prepared in $100 \mu \mathrm{MeOH}$ as the sample standard in the same microplate. $100 \mu \mathrm{L}$ of DPPH reagent was added into all well and kept in the dark for 30 mins. The absorbance was then measured at $517 \mathrm{~nm}$. The percentage inhibition of DPPH activity was calculated based on the following formula:

$\frac{(O D \text { control - ODsample }) \times 100 \%}{O D \text { control }}$

\subsection{UHPLC-MSMS analysis}

Phenolic constituents of sugarcane molasses extract were identified using the Ultra-High Performance Liquid Chromatography-Mass Spectrometer (UHPLC-MS/MS) method. The column used was a Phenomenex Synergy RP C18 column ( $100 \mathrm{~A} \times 100 \mathrm{~mm} \times 3 \mu \mathrm{m} \times 2.0 \mathrm{~mm})$ at a flow rate of $400 \mu \mathrm{L} / \mathrm{min}$ and using $20 \mu \mathrm{L}$ injections. The Flexar UHPLC system was coupled to a Sciex 3200 hybrid trap triple quad tandem mass spectrometer. The mobile phase comprised (A) water and $0.1 \%$ formic acid; and (B) acetonitrile and $0.1 \%$ formic acid. Phenolic compounds were monitored and identified by comparing the chromatographic retention times and total intensity measured. Sciex internal natural product database was used as the mass spectral library for the identification of phenolic compounds. All assays were carried out in triplicate.

\subsection{Test microorganisms}

Four bacterial strains used were two Gram-positive Staphylococcus aureus ATCC 29737, and Listeria monocytogenes ATCC 19112, and two Gram-negative Escherichia coli ATCC 10536 and S. enterica serovar Typhimurium ATCC 13311. The stock cultures of all four bacteria were obtained from the culture collection of 
Laboratory of Food Microbiology, Faculty of Food Science and Technology, Universiti Putra Malaysia.

\subsection{Preparation of test microorganisms}

The stock cultures of the bacteria were sub-cultured on Nutrient agar (Oxoid, UK) at $37^{\circ} \mathrm{C}$ for $24 \mathrm{hrs}$. Colonies of fresh cultures of the different microorganisms from overnight growth were picked and suspended in $3 \mathrm{~mL}$ of Nutrient broth (Oxoid, UK) in falcon tubes and incubated for $24 \mathrm{hrs}$ at $37^{\circ} \mathrm{C}$. Then, the inoculum was diluted in $0.1 \mathrm{M}$ Phosphate-buffered saline (PBS) to standardise density for use in the next assay.

\subsection{Disc diffusion assay}

Antibacterial activities of sugarcane molasses extract were measured by using a standard disc diffusion method (Bauer et al., 1966). Four selected foodborne pathogens; S. aureus ATCC 29737, L. monocytogenes ATCC 19112, E. coli ATCC 10536 and S. enterica serovar Typhimurium ATCC 13311 were prepared in broth dilution series to $10^{5} \mathrm{CFU} / \mathrm{mL}$. $0.1 \mathrm{~mL}$ of the diluted inocula were uniformly spread on Mueller-Hinton (MH) agar (Oxoid, UK) using a sterile cotton swab. Then, the 6 $\mathrm{mm}$ discs filled with different concentrations of diluted molasses extract $(6.25 \%, 12.5 \%$ and $25 \% \mathrm{w} / \mathrm{v})$ were placed on the inoculated MH agar. Sterile distilled water was used as a negative control, and standard ampicillin disc was used as a positive control. The plates were incubated at $37^{\circ} \mathrm{C}$ for $24 \mathrm{hrs}$. The results were obtained by measuring the diameter of the inhibition zone (DIZ).

\subsection{Minimum Inhibitory Concentrations (MICs)}

The minimum inhibitory concentrations (MICs) were measured by the micro dilutions using a 96-well microplate with two-fold serial dilutions $(0.049,0.098$, $0.195,0.391,0.781,1.562,3.125,6.25,12.5,25 \% \mathrm{v} / \mathrm{v})$. All the inhibited bacteria by the treatment of sugarcane molasses extract were used and prepared in a broth dilution series to $10^{5} \mathrm{CFU} / \mathrm{mL}$. $0.1 \mathrm{~mL}$ of inocula were injected into microplate wells 3 to 12 . Then, two-folded serially diluted sugarcane molasses extract was pipetted into the inoculated wells from wells 12 to 3 . Fresh uninoculated $\mathrm{MH}$ broth was used as a positive control and inoculated MH broth was used as a negative control. The microplates were incubated overnight. The turbidity was checked through the Benchmark Plus microplate spectrophotometer (Scopic Resources, Pulau Pinang, Malaysia) to determine the MICs.

\subsection{Minimum Bactericidal Concentrations (MBCs)}

MBC test was performed following the MIC test via a streak plate method. Each sugarcane molasses dilutions with no bacterial growth (light turbidity) from the MIC test was assayed. A loop-full of bacterial strain was inoculated into sterile Mueller-Hinton plates. The plates were then incubated at $37^{\circ} \mathrm{C}$ for $24 \mathrm{hrs}$. The least concentration that did not show any growth of tested organisms was considered as the MBC value of the tested sugarcane molasses extract against the tested bacterial species (Balouiri et al., 2016).

\subsection{Statistical analysis}

The experimental results were statistically analysed using Microsoft Excel 2013. All experiments were performed in triplicate and the results were expressed as average values.

\section{Results and discussion}

\subsection{Total phenolic content of sugarcane molasses extract}

Phenolic compounds are secondary metabolites that can be found in plant tissues which responsible as the bioactive compound. They are made up of hydroxylated aromatic rings attached to the phenyl or aryl group compound (Balasundram et al., 2006). Phenolic compounds are the most abundant structures in plants that possess antioxidant activity through their redox reaction (Johari and Khong, 2019). Total phenolic content is an analysis to measure the amount of phenolic content in one sample. In order to calculate the total phenolic content of sugarcane molasses extract, a gallic acid standard graph was developed (Figure 1) and standard curve $\mathrm{y}=1.506 \ln (\mathrm{x})+0.801$, where $\mathrm{R}^{2}=$ 0.987 . Based on the standard graph, the total phenolic content was expressed as $7.60 \mathrm{mg} \mathrm{GAE} / \mathrm{g}$ extract. This was slightly higher compared with the study by Zhao et al. (2015), $4.32 \mathrm{mg} \mathrm{GAE} / \mathrm{g}$. The result was in agreement with the previous research by Iqbal et al. (2017) in which sugarcane molasses extract exhibited a higher total phenolic compound than other sugarcane by-products due to the high coloured component as a source of phenolic compounds. The high amount of phenolic content in sugarcane molasses extract can be an aid for bioactivity. Thus, the sugarcane molasses extract was expected to have some antioxidant and antibacterial activities.

\subsection{Antioxidant activities of sugarcane molasses extract}

Phenolic compounds in the plant have the ability to scavenge free radical because they contain hydroxyl groups. They can easily donate an atom to the unstable free radical; hence the importance of their antioxidant activity (Kaurinovic and Vastag, 2019). In this study, the DPPH assay was used to evaluate antioxidant properties by estimating free radical scavenging activity. The DPPH free radical has the ability to accept an electron from an antioxidant compound (Aksoy et al., 2013). 


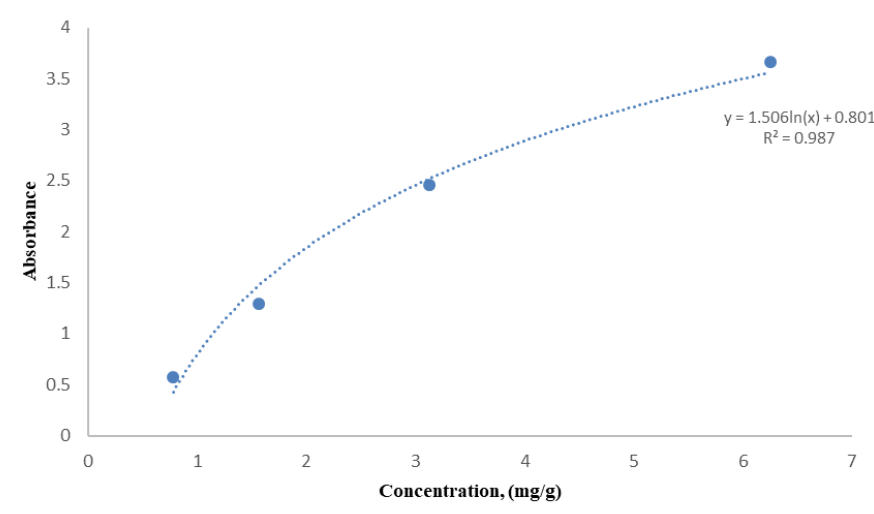

Figure 1. Standard curve of gallic acid.

Figure 2 shows the scavenging of radicals was found high and the $50 \%$ inhibitory concentration $\left(\mathrm{IC}_{50}\right.$ value) was about $0.79 \mathrm{mg} \mathrm{QE} / \mathrm{g}$ sugarcane molasses extract. The concentration for $\mathrm{IC}_{50}$ detected in the extract was notable and resulted in high antioxidant activities. In agreement with the previous study, sugarcane molasses exhibited high antioxidant effect activity with value of $1.9 \mathrm{mg}$ TE$/ \mathrm{g}$ extract (Ali et al., 2019). High antioxidant activity of sugarcane molasses extract has a positive relationship with the total phenolic content. Commonly, the total phenolic compound is correlated to the antioxidant activity. This is because they have the capability to destroy free radicals by transferring their electrons to react with the free radicals (Pior et al., 2005). The antioxidant properties of sugarcane molasses extract might be attributed to the higher phenolic compounds present. The total phenolic compounds and antioxidant properties in sugarcane molasses extract can be an essential parameter response to the presence of antimicrobial activities.

\subsection{Presence of phenolic constituent in sugarcane molasses extract}

UHPLC-MSMS is an analytical technique used as a qualitative analysis of non-volatile compounds such as

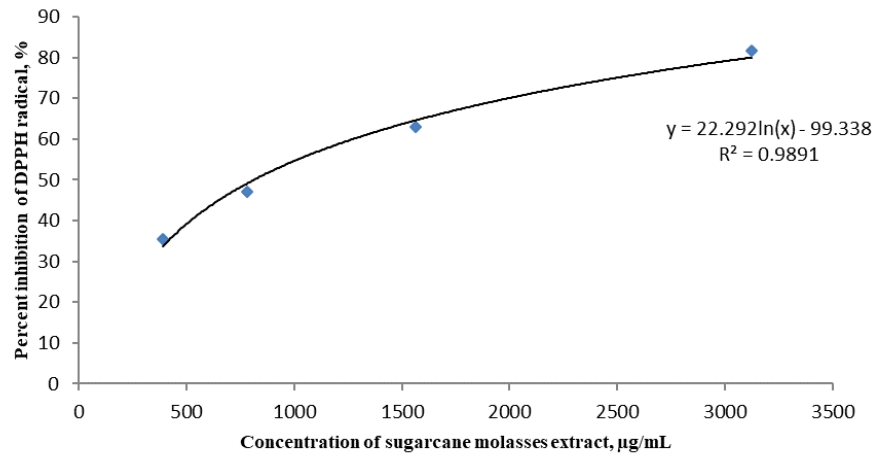

Figure 2. Graph of per cent inhibition of DPPH radical against the concentration of sugarcane molasses extract

phenolics, terpenoids and alkaloids (Kumar, 2017). This analysis was employed to identify the major phenolic constituent present in sugarcane molasses extract. This provides separation of compounds into stationary and mobile phases. In the present study, UHPLC was coupled to a mass spectrometer (MS) to improve and facilitate the detection of metabolites in a better resolution and fast run time. The combination of UHPLC -MS provides excellent selectivity and sensitivity (Lei et al., 2018). Figure 3 represents the major compounds in sugarcane molasses that have been separated through chromatography. Retention time (RT) is responsible for measuring the time taken for a compound to pass chromatography from injection time until the detection time of the particular compounds.

In sugarcane molasses extract, several major phenolic constituents were identified. These were phenylvaleric acid, quinic acid, tannic acid, apigenin and gallic acid as recorded in Table 1. However, there were still several unknown compounds present that not is able to identify in this study. Thus, more work is required to identify these compounds. In UHPLC-MSMS separation and detection, the compound detected with $\mathrm{m} / \mathrm{z}$ value of 175.03 ( $\mathrm{RT}=0.993 \mathrm{~min}$ ) was phenylvaleric acid. The identities of quinic acid, tannic acid, apigenin and gallic

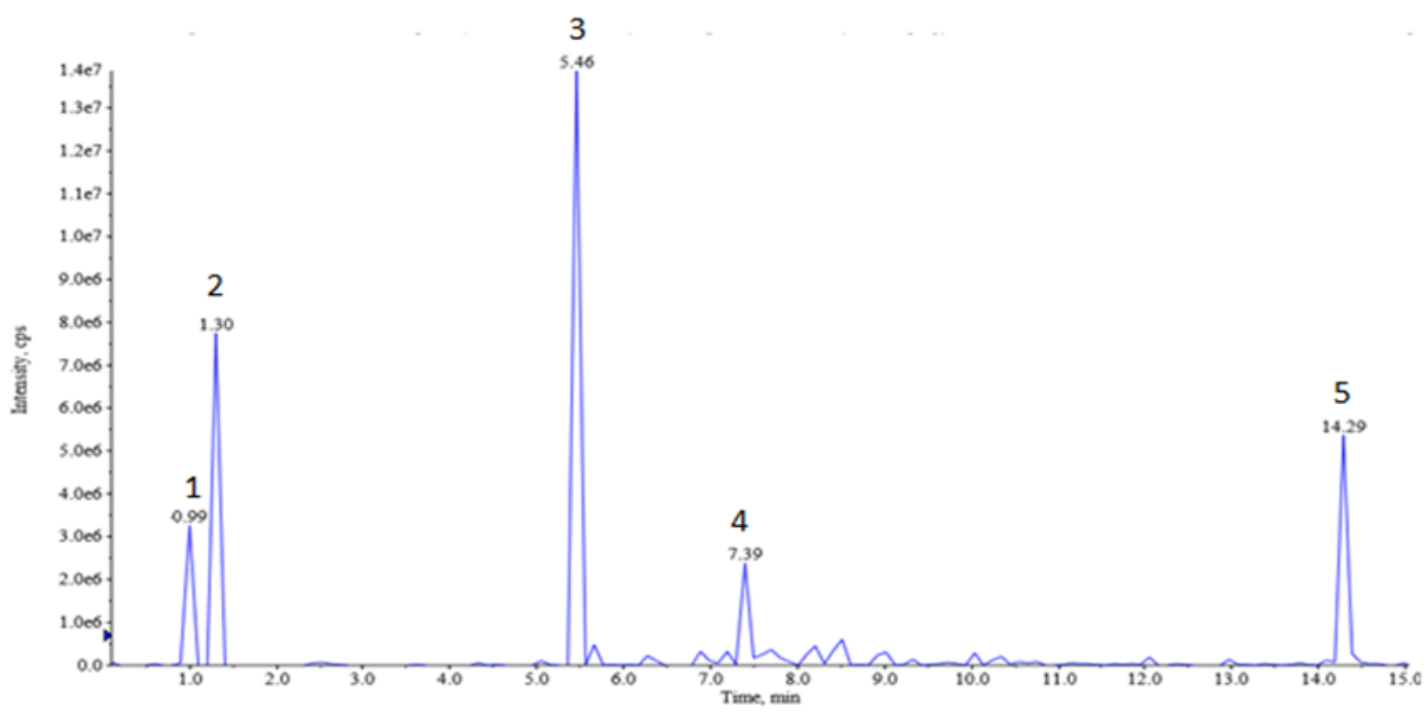

Figure 3. UHPLC-MSMS spectrum of compounds detected in sugarcane molasses extract. 
acid were confirmed from an $\mathrm{m} / \mathrm{z}$ values of $191.22(\mathrm{RT}=$ $1.298 \mathrm{~min}), 183.19(\mathrm{RT}=4.441 \mathrm{~min}), 563.46(\mathrm{RT}=$ $8.205 \mathrm{~min})$ and $169.20(\mathrm{RT}=5.666 \mathrm{~min})$, respectively.

Table 1. Identification of phenolic constituents present in sugarcane molasses extract.

\begin{tabular}{cccc}
\hline $\begin{array}{c}\text { Peak } \\
\text { number }\end{array}$ & $\begin{array}{c}\text { RT } \\
(\mathrm{min})\end{array}$ & $\begin{array}{c}\text { Measured values } \\
(\mathrm{m} / \mathrm{z})\end{array}$ & $\begin{array}{c}\text { Tentative Identity of } \\
\text { Compound }\end{array}$ \\
\hline 1 & 0.993 & 175.03 & Phenylvaleric acid \\
2 & 1.298 & 191.22 & Quinic acid \\
3 & 4.441 & 183.19 & Tannic acid \\
4 & 8.205 & 563.46 & Apigenin \\
5 & 5.666 & 169.2 & Gallic acid \\
\hline
\end{tabular}

Phenolic compounds with less-complex structures possess antimicrobial activities and play essential roles in killing antibiotic-resistant pathogens. Snoch et al. (2019) suggested phenylvaleric acid, which is one of the phenolic acids, has a strong antibacterial effect towards $S$. aureus, C. albicans and E. coli. Quinic acid also has strong antibacterial properties where it can easily attack the intracellular cell of bacteria. Quinic acid has the ability to reduce the succinate dehydrogenase activity and DNA content of bacteria (Bai et al., 2018). Studies by Slobodníková et al. (2016) demonstrated tannic acid which represents one of the most common polyphenols, possess antibacterial against both Gram-positive and Gram-negative bacteria by penetrating the lipid bilayers and damaging their membrane. In short, the phenolic constituents that have been identified in sugarcane molasses extract might have high biological and pharmacological activity hence can be employed as antimicrobial agents in food.

\subsection{Diameter of inhibition zone}

The agar diffusion assay was developed as a primary test to determine the antibacterial activities of an organic or inorganic agent. It showed if the antibacterial agents can inhibit or kill the bacteria. Evaluations of antibacterial activities of sugarcane molasses extracts against four foodborne pathogens are recorded in Table 2 . The results showed that sugarcane molasses extract exhibited significant inhibitory effect towards all tested food-borne pathogens. The mean inhibition zone diameter against L. monocytogenes ATCC 19112, E. coli ATCC 10536 and S. enterica serovar Typhimurium ATCC 13311 in $6.25 \%$ sugarcane molasses extract produced no significant effect, however, Staphylococcus aureus ATCC 29737 showed an inhibition effect with diameter zone $11.67 \pm 1.6 \mathrm{~mm}$. At a concentration of $12.5 \%$ sugarcane molasses extract, both Gram-positive $S$. aureus ATCC 2973 and L. monocytogenes ATCC 19112 had a zone of inhibition of $20.47 \pm 1.6 \mathrm{~mm}$ and $7.60 \pm 1.1 \mathrm{~mm}$, respectively. Meanwhile, for Gramnegative E. coli ATCC 10536 and S. enterica serovar Typhimurium ATCC 13311, the inhibition zones were $6.89 \pm 0.7 \mathrm{~mm}$ and $6.67 \pm 0.4$, respectively. At a concentration of $25 \%$, clear inhibition zones were seen for S. aureus ATCC 2973, L. monocytogenes ATCC 19112, E. coli ATCC 10536 and S. enterica serovar Typhimurium ATCC 13311 at $25.05 \pm 1.6,9.97 \pm 0.2$, $9.01 \pm 0.7$, and $8.82 \pm 0.3 \mathrm{~mm}$, diameter respectively. The antibacterial effect of sugarcane molasses extract was higher for Gram-positive bacteria compared to Gramnegative bacteria. S. aureus ATCC 2973 was found to be the most sensitive to the antibacterial effect of sugarcane molasses extract. This study showed Gram-positive bacteria were easier to be inhibited by the sugarcane molasses extract compared to Gram-negative bacteria. The previous study also reported the antibacterial effects of sugarcane bagasse extract, a by-product of sugar manufacturing, were significantly higher in Grampositive bacteria compared to Gram-negative bacteria (Zhao et al., 2015). This is in contrast to Chen et al. (2017) reported that Gram-negative bacteria was the one that can be inhibited more easily by the molasses compared to Gram-positive bacteria.

The different results observed in antibacterial activity may be due to the differences in susceptibility of each species of bacterium rather than merely a difference between Gram-positive and Gram-negative bacteria. Gram-negative bacteria are highly resistant to the sugarcane molasses extract may be due to their complex membrane that blocks the diffusion of foreign materials (Dahl et al., 1989). Besides, the inconsistency of results

Table 2. Antibacterial properties of sugarcane molasses extract against selected foodborne pathogens using disc diffusion assay

\begin{tabular}{lccccc}
\hline & \multicolumn{4}{c}{ The diameter of the inhibition zone, DIZ (mm) } \\
\cline { 2 - 6 } \multicolumn{1}{c}{ Microorganism } & \multicolumn{2}{c}{ Sugarcane molasses extract, w/v } & \multicolumn{2}{c}{ Control } \\
\cline { 2 - 6 } & $6.25 \%$ & $12.50 \%$ & $25 \%$ & $\begin{array}{c}\text { Positive (Amoxicillin } \\
30 \mu \mathrm{g} / \mathrm{mL})\end{array}$ & $\begin{array}{c}\text { Negative } \\
\text { (Sterile distilled } \\
\text { water) }\end{array}$ \\
\hline S. aureus ATCC 29737 & $11.67 \pm 1.6$ & $20.47 \pm 1.6$ & $25.05 \pm 1.6$ & $29.29 \pm 0.4$ & $\mathrm{NIZ}$ \\
L. monocytogenes ATCC 19112 & $\mathrm{NIZ}$ & $7.60 \pm 1.1$ & $9.97 \pm 0.2$ & $13.57 \pm 1.6$ & $\mathrm{NIZ}$ \\
$\begin{array}{l}\text { E. coli ATCC 10536 } \\
\text { S. enterica ser. Typhimurium ATCC 13311 }\end{array}$ & $\mathrm{NIZ}$ & $6.89 \pm 0.7$ & $9.01 \pm 0.7$ & $21.47 \pm 0.5$ & $\mathrm{NIZ}$ \\
\hline
\end{tabular}

*: The inhibition zones (in diameter) were included $6 \mathrm{~mm}$ of the disc, : (NIZ) means no inhibition zone. 
between our results and those of others may relate to the cultivation of sugarcane and the effect of geographical area (Tumin et al., 2005).

\subsection{MIC and MBC of sugarcane molasses extract}

The minimum inhibitory concentration (MIC) and minimum bactericidal concentration (MBC) tests were used to observe the inhibition of growth and eradication of bacteria, respectively. This study refers to MIC as the lowest concentration required to inhibit $99 \%$ of bacterial growth. Meanwhile, MBC is defined as the lowest concentration needed to kill at least $99 \%$ of the bacteria.

The minimum inhibitory concentration (MIC) and minimum bactericidal concentration (MBC) of sugarcane molasses extract towards four food-borne pathogens; $S$. aureus ATCC 29737, L. monocytogenes ATCC 19112, $E$. coli ATCC 10536 and $S$. enterica serovar Typhimurium ATCC 13311 are detailed in Table 3. The results showed MIC values lie between $3.125 \%$ and $12.5 \%$ respectively, for the four bacteria. The lowest MIC values $(3.125 \%)$ were observed on the sugarcane molasses extract towards both Gram-positive bacteria, $S$ aureus ATCC 29737 and L. monocytogenes ATCC. Meanwhile, the extract against both Gram-negative bacteria, E. coli ATCC 10536 and S. enterica serovar Typhimurium ATCC 13311 was one fold more than the inhibition of the other bacteria with values of $6.25 \%$.

Table 3. Minimum inhibitory concentration (MIC) and minimum bactericidal concentration (MBC) of sugarcane molasses extract against selected foodborne pathogens

\begin{tabular}{lcc}
\hline Microorganism & MICs (v/v) & MBCs (v/v) \\
\hline S. aureus ATCC 29737 & $3.13 \%$ & $6.25 \%$ \\
L. monocytogenes ATCC 19112 & $3.13 \%$ & $6.25 \%$ \\
E. coli ATCC 10536 & $6.25 \%$ & $12.50 \%$ \\
S. enterica ser. Typhimurium & $6.25 \%$ & $>12.5 \%$ \\
\hline
\end{tabular}

Minimum bactericidal concentrations can be affected by ethanol extraction. These effects were also observed against four microorganisms tests which are $S$. aureus ATCC 29737, L. monocytogenes ATCC 19112, E. coli ATCC 10536 and S. enterica serovar Typhimurium ATCC 13311 for sugarcane molasses extract. Based on Kang et al. (2011), the value of the lowest MBC obtained was not more four times higher than that of MIC's for a particular pathogen. The lowest MBC (6.25\%) was obtained for S. aureus ATCC 29737 and $L$. monocytogenes ATCC 19112 in this study. Meanwhile, the highest $\mathrm{MBC}$ values were $(>12.5 \%)$ obtained from $S$. Typhimurium ATCC 13311. The values were not more than four times greater than that of the MIC's for the corresponding microorganism (Table 3). From this study, we conclude that Gram-positive bacteria were more sensitive to sugarcane molasses extract compared to the Gram-negative bacteria.

Higher inhibition against Gram-positive bacteria may be due to the composition and the structure of the cell wall (Delgado-Adámez et al., 2012; Zhao et al., 2015). The thick peptidoglycan with a sensitive layer in Gram-positive, bacteria can be penetrated by foreign materials and absorbed into easily. This characteristic provides a high opportunity for the sugarcane molasses extract to disrupt the cell wall synthesis of bacteria, thus causing death, (Guerra-Rosas et al., 2017). The lower bacteriostatic activity was found with Gram-negative bacteria. The less susceptibility of these isolates towards sugarcane molasses extracts may be due to the presence of the lipopolysaccharide layer which limits the diffusion of hydrophobic compounds (Dahl et al., 1989; Adamez et al., 2012; Zhao et al., 2015; Chen et al., 2017). Gramnegative bacteria also have an outer membrane with an external monolayer of lipopolysaccharide which was robust and highly impermeable to toxins and antibacterial agents (Arunmanee et al., 2016).

\section{Conclusion}

In conclusion, the results obtained in the present study indicate that sugarcane molasses extract is a valuable by-product, which contains various polyphenol compounds that contribute to the antioxidant and antibacterial properties. The total phenolic content in this extract was evaluated and found to be high in comparison to previous studies. The extract also showed antioxidant capabilities and had high antibacterial activity towards selected foodborne pathogens. Sugarcane molasses may be applied as an alternative antibacterial compound. However, this needs to be confirmed by the application of sugarcane molasses extract in the food system.

\section{Conflict of Interest}

The authors declare no conflict of interest.

\section{Acknowledgement}

The authors would like to thank Universiti Putra Malaysia for financial support throughout this research with the Putra Grant Scheme (GP/2018/967100).

\section{References}

Arunmanee, W., Pathania, M., Solovyova, A.S., Le Brun, A.P., Ridley, H., Baslé, A., van den Berg, B. and Lakey, J.H. (2016). Gram-negative trimeric porins have specific LPS binding sites that are essential for porin biogenesis. Proceedings of the National Academy of Sciences, 113(34), E5034- 
E5043. https://doi.org/10.1073/pnas.1602382113

Abas, F., Khatib, A., Shaari, K. and Lajis, N.H. (2014). Chemical characterization and antioxidant activity of three medicinal Apiaceae species. Industrial Crops and Products, 55, 238-247. https://doi.org/10.1016/ j.indcrop.2014.02.013

Abbas, S.R., Sabir, S.M., Ahmad, S.D., Boligon, A.A. and Athayde, M.L. (2014). Phenolic profile, antioxidant potential, and DNA damage protecting the activity of sugarcane (Saccharumofficinarum). Food Chemistry, 147, 1016. https://doi.org/10.1016/j.foodchem.2013.09.113

Adámez, J.D., Samino, E.G., Sánchez, E.V. and González-Gómez, D. (2012). In vitro estimation of the antibacterial activity and antioxidant capacity of aqueous extracts from grape-seeds (Vitisvinifera L.). Food Control, 24(1-2), 136-141. https:// doi.org/10.1016/j.foodcont.2011.09.016

Aksoy, L., Kolay, E., Ağılönü, Y., Aslan, Z. and Kargioğlu, M. (2013). Free radical scavenging activity, total phenolic content, total antioxidant status, and total oxidant status of endemic Thermopsis turcica. Saudi Journal of Biological Sciences, 20(3), 235-239. https://doi.org/10.1016/ j.sjbs.2013.02.003

Ali, S.E., El Gedaily, R.A., Mocan, A., Farag, M.A. and El-Seedi, H.R. (2019). Profiling Metabolites and Biological Activities of Sugarcane (Saccharum officinarum Linn.) Juice and Its Product Molasses via a Multiplex Metabolomics Approach. Molecules, 24(5), $934 . \quad$ https:// doi.org/10.3390/molecules24050934

Arimi, M.M., Zhang, Y., Gotz, G., Kiriamiti, K. and Geiben, S.-U. (2014) Antibacterial colorants in molasses distillery wastewater and their removal technologies. International Biodeterioration and Biodegradation, 87, 34-43. https://doi.org/10.1016/ j.ibiod.2013.11.002

Arshad, M.S. and Batool, S.A. (2017). Natural Antimicrobials, their Sources and Food Safety. In Karunaratne, D.N. and Pamunuwa, G. (Eds.) Food Additives. InTechOpen E-Book. https:// doi.org/10.5772/intechopen.70197

Bai, J., Wu, Y., Wang, X., Liu, X., Zhong, K., Huang, Y., Chen, Y. and Gao, H. (2018). In vitro and in vivo characterization of the antibacterial activity and membrane damage mechanism of quinic acid against Staphylococcus aureus. Journal of Food Safety, 38 (1), e12416. https://doi.org/10.1111/jfs. 12416

Balasundram, N., Sundram, K. and Samman, S. (2006). Phenolic compounds in plants and agri-industrial byproducts: Antioxidant activity, occurrence, and potential uses. Food Chemistry, 99(1), 191-203. https://doi.org/10.1016/j.foodchem.2005.07.042

Balouiri, M., Sadiki, M. and Ibnsouda, S.K. (2016). Methods for in vitro evaluating antimicrobial activity: A review. Journal of Pharmaceutical Analysis, 6(2), 71-79. https://doi.org/10.1016/ j.jpha.2015.11.005

Bauer A.W., Kirby W.M., Sherris J.C. and Turck M. (1966). Antibiotic susceptibility testing by a standardized single disk method. American Journal of Clinical Pathology, 45(4), 493-496. https:// doi.org/10.1093/ajcp/45.4_ts.493

Bilal, M., Rasheed, T., Iqbal, H.M., Hu, H., Wang, W. and Zhang, X. (2017). Macromolecular agents with antimicrobial potentialities: A drive to combat antimicrobial resistance. International Journal of Biological Macromolecules, 103, 554-574. https:// doi.org/10.1016/j.jibiomac.2017.05.071

Chandra, R., Bharagava, R.N. and Rai, V. (2008). Melanoidins as major colourant in sugarcane molasses based distillery effluent and its degradation. Bioresource Technology, 99(11), 46484660. https://doi.org/10.1016/j.biortech.2007.09.057

Chen, M., Zhao, Y., Chen, F., Zhao, Z., Yu, S. and Abbasi, A.M. (2015). An HPLC-DPPH method for antioxidant activity from sugarcane molasses. Sugar Industry, 140(10), 632-639.

Dahiya, P. and Purkayastha, S. (2012). Phytochemical screening and antimicrobial activity of some medicinal plants against multi-drug resistant bacteria from clinical isolates. Indian Journal of Pharmaceutical Sciences, 74(5), 443. https:// doi.org/10.4103/0250-474X.108420

Dhama, K., Tiwari, R., Chakraborty, S., Saminathan, M., Kumar, A., Karthik, K. and Rahal, A. (2014). Evidence based antibacterial potentials of medicinal plants and herbs countering bacterial pathogens especially in the era of emerging drug resistance: An integrated update. International Journal of Pharmacology, 10(1), 1-43. https://doi.org/10.3923/ ijp.2014.1.43

Dahl, T.A., Midden, W.R. and Hartman, P.E. (1989). Comparison of killing of gram-negative and grampositive bacteria by pure singlet oxygen. Journal of Bacteriology, 171(4), 2188-2194.

Edeoga, H.O., Okwu, D.E. and Mbaebie, B.O. (2005). Phytochemical constituents of some Nigerian medicinal plants. African Journal of Biotechnology, 4(7), 685-688. https:// doi.org/10.1128/JB.171.4.2188-2194.1989

Guerra-Rosas, M. I., Morales-Castro, J., CuberoMárquez, M. A., Salvia-Trujillo, L. and Martín- 
Belloso, O. (2017). Antimicrobial activity of nanoemulsions containing essential oils and high methoxyl pectin during long-term storage. Food Control, 77, 131-138. https://doi.org/10.1016/ j.foodcont.2017.02.008

Guimarães, C.M., Giao, M.S., Martinez, S.S., Pintado, A.I., Pintado, M.E., Bento, L.S. and Malcata, X.F. (2007) Antioxidant activity of sugar molasses, including protective effect against DNA oxidative damage. Journal of Food Science, 72(1), C039C045. https://doi.org/10.1111/j.1750-

3841.2006.00231.x

Iqbal, M., Qamar, M.A., Bokhari, T.H., Abbas, M., Hussain, F., Masood, N., Keshavarzi, A., Qureshi, N. and Nazir, A. (2017) 'Total phenolic, chromium contents and antioxidant activity of raw and processed sugars', Information Processing in Agriculture, 4(1), 83-89. https://doi.org/10.1016/ j.inpa.2016.11.002

Johari, M.A. and Khong, H.Y. (2019). Total Phenolic Content and Antioxidant and Antibacterial Activities of Pereskia bleo. Advances in Pharmacological Sciences, 2019, $7428593 . \quad \mathrm{https}: / /$ doi.org/10.1155/2019/7428593

Kang, C.G., Hah, D.S., Kim, C.H., Kim, Y.H., Kim, E. and Kim, J.S. (2011). Evaluation of antimicrobial activity of the methanol extracts from 8 traditional medicinal plants. Toxicological Research, 27(1), 3136. https://doi.org/10.5487/TR.2011.27.1.031

Kaurinovic, B. and Vastag, D. (2019). Flavonoids and Phenolic Acids as Potential Natural Antioxidants. In Shalaby, E. (Ed.) Antioxidants. IntechOpen EBooks. https://doi.org/10.5772/intechopen.83731

Kumar, B.R. (2017). Application of HPLC and ESI-MS techniques in the analysis of phenolic acids and flavonoids from green leafy vegetables (GLVs). Journal of Pharmaceutical Analysis, 7(6), 349-364. https://doi.org/10.1016/j.jpha.2017.06.005

Lei, Z., Sumner, B.W., Bhatia, A., Sarma, S.J. and Sumner, L.W. (2019). UHPLC-MS Analyses of Plant Flavonoids. Current Protocols in Plant Biology, 4(1), e20085. https://doi.org/10.1002/ cppb. 20085

Olbrich, H. (2006). The molasses., p. 131. BiotechnologieKempe $\mathrm{GmbH}$. Retrieved from website: http://www.biotechnologie-kempe.de/ Molasses_OLBRICH.pdf

Mohamad, H., Abas, F., Permana, D., Lajis, N.H., Ali, A.M., Sukari, M.A., Hin, T.Y.Y., Kikuzaki, H. and Nakatani, N. (2004). DPPH free radical scavenger components from the fruits of Alpinia rafflesiana Wall. ex. Bak.(Zingiberaceae). Zeitschrift für
Naturforschung C, 59(11-12), 811-815. https:// doi.org/10.1515/znc-2004-11-1208

Mohanraj, R. and Sivasankar, S. (2014). Sweet Potato (Ipomoea batatas [L.] Lam)-A valuable medicinal food: A review. Journal of Medicinal Food, 17(7), 733-741. https://doi.org/10.1089/jmf.2013.2818

Nychas, G.J.E. (1995). Natural antimicrobials from plants. In New methods of food preservation, p. 5889. Boston, Massachusetts, USA: Springer. https:// doi.org/10.1007/978-1-4615-2105-1_4

Saeed, F., Afzaal, M., Tufail, T. and Ahmad, A. (2019). Use of Natural Antimicrobial Agents: A Safe Preservation Approach. In Var, I. (Ed.) Active Antimicrobial Food Packaging. IntechOpen E-Book. https://doi.org/10.5772/intechopen.80869

Saska, M. and Chou, C.C. (2002). Antioxidant properties of sugarcane extracts. In Proceedings of First Biannual World Conference on Recent Developments in Sugar Technologies, Delray Beach, Florida, USA.

Slobodníková, L., Fialová, S., Rendeková, K., Kováč, J. and Mučaji, P. (2016). Antibiofilm activity of plant polyphenols. Molecules, 21(12), 1717. https:// doi.org/10.3390/molecules21121717

Snoch, W., Stępień, K., Prajsnar, J., Staroń, J., Szaleniec, M. and Guzik, M. (2019). Influence of Chemical Modifications of Polyhydroxyalkanoate-Derived Fatty Acids on Their Antimicrobial Properties. Catalysts, 9(6), 510. https:// doi.org/10.3390/catal9060510

Takara, K., Ushijima, K., Wada, K., Iwasaki, H. and Yamashita, M. (2007). Phenolic compounds from sugarcane molasses possessing antibacterial activity against cariogenic bacteria. Journal of oleo science, 56(11), 611-614. https://doi.org/10.5650/jos.56.611

Tumin, N., Halim, N.A., Shahjahan, M., Noor Izani, N.J., Sattar, M.A., Khan, A.H. and Mohsin, S.S.J. (2005). Antibacterial activity of local Malaysian honey. Malaysian Journal of Pharmaceutical Sciences, 3(2), 1-10.

Valli, V., Gomez-Caravaca, A.M., Nunzion, M.D., Danesi, F., Caboni, M.F. and Bordoni, A. (2012) Sugarcane and Sugar Beet Molasses, Antioxidantrich Alternatives to Refined Sugar. Journal of Agricultural and Food Chemistry, 60, 12508-12515. https://doi.org/10.1021/jf304416d

Zhao, Y., Chen, M., Zhao, Z. and Yu, S. (2015). The antibiotic activity and mechanisms of sugarcane (Saccharumofficinarum L.) bagasse extract against food-borne pathogens. Food Chemistry, 185, 112118. https://doi.org/10.1016/j.foodchem.2015.03.120 